\title{
Assessment of the antinociceptive effects of cannabinoid receptor agonists SER 601 and $L-759,633$ in an acute pain model in rats
}

\section{Kannabinoid \\ L-759,633'ün \\ reseptör \\ agonistleri \\ SER \\ 601 ve \\ ratlarda \\ akut \\ ağrı \\ modelindeki \\ antinosiseptif etkilerinin araştırılması}

Ziad Joha, Şahin Yılldırım, Büllent Saraç

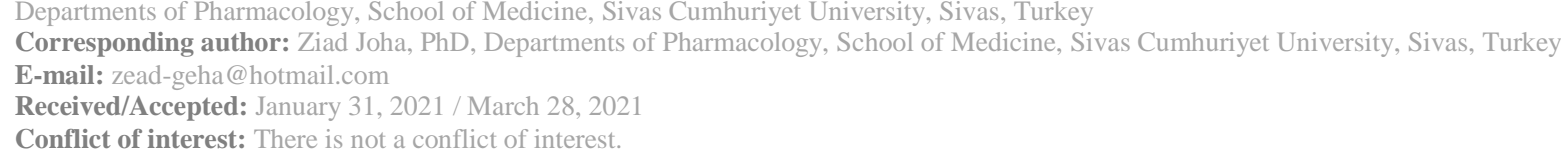

\section{SUMMARY}

A poorly managed pain is associated with many negative results. These results disturb patients, their families and societies. Although opioid agents have extraordinary analgesic efficacy, they may cause serious adverse consequences. For medication of pain, there is a medical need to discover possible alternatives to opioids. In animal models of acute pain synthetic cannabinoid receptor agonists demonstrated analgesic effects. Selective activation of the cannabinoid 2 receptor in the rodent models does not cause psychotropic effects therefore $\mathrm{CB}_{2} \mathrm{R}$ agonists are an appealing target for the medication of pain and other pathologies. In this study we examined the antinociceptive activity of cannabinoid receptor $2\left(\mathrm{CB}_{2}\right)$ agonists SER 601 and L-759,633 in different doses in rat models of acute pain using the hot plate and tail flick tests. These two agents exhibited dose-dependent antinociceptive effects in acute pain model. The analgesic effects of the administrated doses of L-759,633 and SER 601 reached their peak at $60 \mathrm{~min}$. In the tail flick test, the antinociceptive effects of 3,6 and $12 \mathrm{mg} / \mathrm{kg}$ SER601 in the acute pain were more than the L-759,633 groups at the same doses.

Keywords: Acute pain, cannabinoid receptor 2 agonists, tail flick, hot plate
(iD) Ziad Joha
(iD) ŞahinYıldırım
(iD) Bülent Saraç

ORCID IDs of the authors:

Z.J. 0000-0001-8520-3760

Ş.Y. 0000-0003-1312-7273

B.S. 0000-0002-0799-0647

\section{ÖZET}

Kötü bir şekilde yönetilen ağrı birçok olumsuz sonuçla ilișkilidir. Bu sonuçlar hastaları, ailelerini ve toplumu bir bütün olarak birlikte etkiler. Opioid ajanları olağanüstü analjezik etkinliğe sahip olsalar da ciddi olumsuz sonuçlara neden olabilirler. Ağrı tedavisi için, opioidlere yararlı bir alternatifleri keşfetmeye yönelik tıbbi bir ihtiyaç vardır. Akut ağrının hayvan modellerinde sentetik kanabinoid reseptörü agonistleri analjezik etki göstermişler. Kemirgen modellerinde kannabinoid 2 reseptörünün seçici aktivasyonu, psikotropik etkilere neden olmaz. Bu nedenle $\mathrm{CB}_{2} \mathrm{R}$ agonistleri, ağr1 ve diğer patolojilerin tedavisi için çekici bir hedeftir. Bu çalışmada kannabinoid reseptör $2\left(\mathrm{CB}_{2}\right)$ agonistleri SER 601 ve L-759,633'ün farkl1 dozlarda antinosiseptif aktivitelerini hot plate ve tail flick testlerini kullanarak akut ağrı rat modelinde inceledik. Bu iki ajan, akut ağr1 modelinde doza bağlı antinosiseptif etki gösterdiler. L-759,633 ve SER 601 dozlarının analjezik etkileri 60 dakikada zirveye ulaştı. Tail flick testinde SER601'in 3, 6, 12 mg/kg dozların akut ağrı üzerindeki etkileri aynı dozlardaki L-759,633 gruplarına göre daha fazladır

Anahtar sözcükler: Akut ağrı, kannabinoid reseptör 2 agonist, tail flick, hot plate 


\section{INTRODUCTION}

Pain is an undesirable action resulting from both physical and psychological replies to injury. Pain messages are conveyed by a complex array of pathways from the periphery to the central nervous system ${ }^{1}$. Acute pain involves stimulation of nociceptors, chemical mediators and inflammation ${ }^{2}$. Nociceptive pain is a pain produced by activation of peripheral nerve endings (nociceptors) which replies to harmful stimulation. Nociceptive pain is caused by certain or probable damage to non-neural tissue ${ }^{3}$. Events which occur during pain include transduction, transmission, perception and modulation ${ }^{4}$. Medicines can be used to target each of the important factors in the pain circuit and to eliminate or diminish the pain sensation. When acute pain is properly managed, the clinical outcomes of the patient and his fulfillments are improved ${ }^{2}$. A poorly managed pain has caused many negative results. They disturb patients, and their families and societies. These results can be classified generally as psychosocial (quality of life), physiological and financial consequences ${ }^{5,6}$. Opioid agents exhibit antinociceptive effects via mu-opioid receptor and are often used for the treatment of acute and chronic pain. Although opioid agents have extraordinary analgesic efficacy, they may cause serious adverse consequences. For instance, a prolonged use of opioids produces tolerance, physical dependence and abuse ${ }^{7}$. In 2015, there were more than 33,000 opioid overdose attributed death cases in the United States. For pain medication, there is a medical need to discover possible alternatives to opioids ${ }^{8}$. The endocannabinoid system is present along pain pathways and it includes cannabinoid 1 receptors $\left(\mathrm{CB}_{1} \mathrm{R}\right)$, cannabinoid 2 receptors $\left(\mathrm{CB}_{2} \mathrm{R}\right)$, endogenous cannabinoid ligands (endocannabinoids) and metabolizing enzymes ${ }^{9}$. In animal models of acute, inflammatory and neuropathic pain endocannabinoids and synthetic cannabinoid receptor agonists have demonstrated analgesic effects ${ }^{6} . \mathrm{CB}_{1} \mathrm{R}$ and $\mathrm{CB}_{2} \mathrm{R}$ are placed in the peripheral, spinal or supraspinal regions. They are also essential targets which mediate these analgesic effects. The cannabinoids antinociceptive effect mechanisms contain presynaptic neurotransmitter and neuropeptide release reduction, postsynaptic neuronal excitability modulation, descending pathway of pain activation and neuroinflammatory signals inhibition. Enormous preclinical evidences supporting cannabinoids as potential antinociceptive agents are supported by clinical studies which are showing their effectiveness in different types of pain ${ }^{6}$. Cannabinoid 1 receptor $\left(\mathrm{CB}_{1} \mathrm{R}\right)$ agonists and nonselective cannabinoid receptor agonists cause several drawbacks, although they exhibit effective analgesic effects in human use as well as in rodent models. These agents produce tolerance, psychotomimetic effects, and many other adverse effects ${ }^{10,11}$. On the other hand, the selective activation of the cannabinoid 2 receptor in the rodent models does not caused these psychotropic effects 12, 13 therefore $\mathrm{CB}_{2} \mathrm{R}$ agonists are an appealing target for the medication of pain and other pathologies. In fact, these agents have been demonstrated to reduce acute, inflammatory, and chronic pain making them to acquire more attention as a possible alternative to the usage of opioids for pain alleviation ${ }^{14}$. Using the hot plate and tail flick tests, this study examined the antinociceptive activity of Cannabinoid Receptor $2\left(\mathrm{CB}_{2}\right)$ agonists SER 601 and L-759,633 in different doses in acute pain rat models.

\section{MATERIAL AND METHODS}

This work stems from the doctoral thesis tilted "Investigation of the Analgesic Effects of Drugs that Affect Cannabinoidergic System in Acute Pain and Experimental Neuropathic Pain Model in Rats"

\section{Animals}

Experiments were conducted on adult male Wistar albino rats weighing 200-225 g. The rats were accommodated to the environment under temperature and humidity-controlled conditions $\left(22 \pm 1{ }^{\circ} \mathrm{C}, 50 \pm 5 \%\right.$ humidity), four in each cage, and maintained with 12-hour dark/12-hour light cycles with sufficient food and water. Each experimental group had 6 rats. Experiment protocols were approved by sivas Cumhuriyet University Animal Ethics Committee. The animals were habituated to laboratory conditions prior to testing. All experiments were performed blindly between 10 and 15 hours.

$(6 \mathrm{aR}, 10 \mathrm{aR})-3$ - (1,1 -Dimethylheptyl) - 6a, 7, 10, 10a - tetrahydro - 1 - methoxy - 6,6,9 trimethyl - 6H -dibenzo [b,d] pyran (L-759,633) (Cayman Chemical Company, USA) and $\mathrm{N}$ (Adamant-1-yl) - 6 - isopropyl - 4 - oxo - 1 pentyl - 1,4-dihydroquinoline - 3 - carboxamide (SER601) (Cayman Chemical Company, USA) were dissolved in DMSO. Solutions were freshly prepared on the days of experimentation. SER601, L-759,633 (a CB2 receptor agonists, 3, 6, 12 $\mathrm{mg} / \mathrm{kg}$ ) were administered intraperitoneally before the analgesia tests. 


\section{Analgesia Tests}

Standard tail flick test (May TF 0703 Tail beat unit, Commat) and hot plate test (May AHP 0603 Analgesic HP, Commat) devices were used to assess thermal pain. In the tail flick method, the radiant heat source was applied to a $3 \mathrm{~cm}$ distal portion of the tails of the rats after vehicle or test agents were administered intraperitoneally. Tailflick latencies (TFL) were obtained after applying radiant heat. A cut off time of 15 second was selected to avoid tissuelinjury. Rats that did not respond after 15 seconds were excluded from the study. The hyperalgesic responses in this test are attributed to the mechanisms of pain in the CNS ${ }^{15}$, 16.

In the hot plate test, the rats were put on a hot plate (May AHP 0603 Analgesic Hot Plate; Commat) with the temperature set at $53 \pm 0.5^{\circ} \mathrm{C}$. To avoid heat, the latency to the first sign of paw licking or jumping response was taken as an index of the threshold of pain. The cut off time of 15 second was selected to prevent damaging the claw. The hyperalgesic responses in this test are attributed to the mechanisms of pain in both the central and peripheral nervous systems ${ }^{15}$.

\section{Protocol}

Animals were randomly divided into 7 groups. Each group includes six rats. DMSO was applied to the rats in the control group. Drugs were administered in 3 different doses. The antinociceptive effects of SER601 and L-759,633 were considered at $0,15,30,60,90$, and 120 minutes using tail-flick and hot-plate tests.

\section{Data Analysis}

To calculate percentage of the maximum possible effect (\% MPE), lick/escape latencies (hot plate) and tail withdrawal latencies (tail flick) were transformed to percentage of anti-nociceptive effects using this equation:

$\%$ MPE $=\{($ test latency - baseline $) /($ cutoff baseline) $\}^{*} 100$

\section{Statistical Analysis}

For each rat in the all groups the anti-nociceptive effects of the agents were obtained as tail flick and hot plate latencies and converted to MPE \%. The data were analyzed using two-way ANOVA and repeated measures ANOVA followed by a Tukey post hoc test (SPSS 14.0 for Windows) for multiple comparisons between groups. All data are presented as a mean \pm SEM. Significance level was determined as $\mathrm{p}<0.05$.

\section{RESULTS}

\section{The Antinociceptive Effects of Different Doses of SER601 in the Acute Pain Model}

The antinociceptive effects of different doses of SER601 $(3,6,12 \mathrm{mg} / \mathrm{kg})$ in acute pain were estimated by measuring anti-hyperalgesic responses for these doses of SER601 at 15, 30, 60, 90, and 120 minutes by tail flick and hot plate methods. In the tail flick test, $12 \mathrm{mg} / \mathrm{kg}$ SER601 showed antinociceptive effect in acute pain at all minute points except at the $120 \mathrm{~min}$., but 3 and 6 $\mathrm{mg} / \mathrm{kg}$ SER601 showed this effect at 30,60 and 90 mins compared to the control group (Fig. 1A). In the hot plate test, $12 \mathrm{mg}$ SER601 was found to have antinociceptive effect in acute pain at all minute points, $6 \mathrm{mg} / \mathrm{kg}$ SER601 at all minute points except at the $15-\mathrm{min}$, and $3 \mathrm{mg} / \mathrm{kg}$ SER601 at the 30,60 and 90-mins compared to the control group (Fig. 1B). The differences between \% MPE values obtained by these three doses were shown to be statistically significant in both tail flick and hot plate tests (Fig. 1). Thus the effect of this agent against acute pain was demonstrated to be dose-dependent. The analgesic effects of the administrated doses of SER601 reached their peak at the 60-min. In the tail flick test, the obtained \% MPE values by 3, 6 and $12 \mathrm{mg} / \mathrm{kg}$ SER601 at the 60-min were respectively: $78.15 \pm 5.34,96.85 \pm$ $2.01,98.48 \pm 1.51$ while in the hot plate test, the obtained values were respectively $28.58 \pm 1.42$, $40.43 \pm 3.19,51.45 \pm 3.11$. 

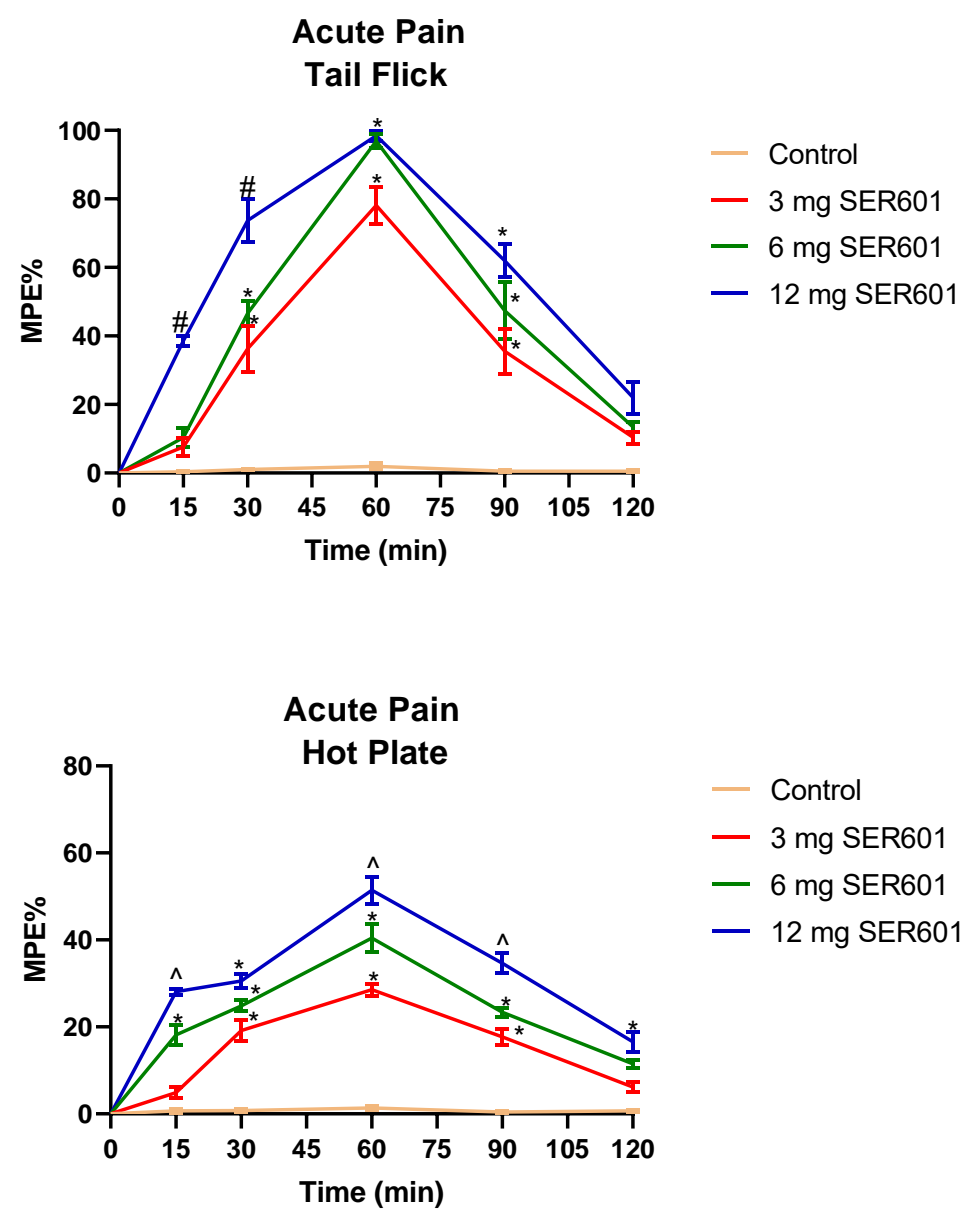

Fig. 1: The antinociceptive effects of different doses of SER601 in the acute pain model using tail flick test (A) and hot plate test (B).These effects were expressed as percent of maximal possible effect (MPE). SER601 was applied intraperitoneally. Each point represents the mean \pm SEM of \% MPE for 6 rats. $\left({ }^{*}\right)$ There was a significant analgesic effect compared to the control group $(* \mathrm{p}<0.05)(\wedge)$ There was a significant analgesic effect compared to the control group and this analgesic effect was significantly higher than that of $3 \mathrm{mg} / \mathrm{kg}$ SER601 group ( $\wedge \mathrm{p}<0.05)$. (\#)There was a significant analgesic effect compared to the control group and this analgesic effect was significantly higher than that of 3 and $6 \mathrm{mg} / \mathrm{kg}$ SER601 groups (\#p <0.05).

\section{The Antinociceptive Effects of Different Doses of L-759,633 in the Acute Pain Model}

The antinociceptive effects of different doses of L-759,633 $(3,6,12 \mathrm{mg} / \mathrm{kg})$ in acute pain were determined by measuring anti-hyperalgesic responses for these doses of L-759,633 at 15, 30, 60,90 , and 120 minutes by tail flick and hot plate methods. In the tail flick test, $12 \mathrm{mg} / \mathrm{kg} \mathrm{L}-759,633$ showed antinociceptive effect in acute pain at all minutes except $15-\mathrm{min}, 6 \mathrm{mg} \mathrm{L}-759,633$ at all minutes except 15 and 120 -mins, and $3 \mathrm{mg} \mathrm{L}$ 759,633 at 60 -min compared to the control group (Fig. 2A). In the hot plate test, $12 \mathrm{mg} / \mathrm{kg} \mathrm{L}$ 759,633 was found to have antinociceptive effect in acute pain at all minutes, $6 \mathrm{mg} \mathrm{L-759,633} \mathrm{at} \mathrm{all}$ minutes except 90 and 120-mins, and $3 \mathrm{mg} \mathrm{L}-$
759,633 at 30 and 60-mins compared to the control group (Fig. 2B). The differences between $\%$ MPE values obtained by these three doses were reported to be statistically significant in both tail flick and hot plate tests (Fig. 2). Thus the effect of this drug in acute pain was demonstrated to be dose-dependent. The analgesic effects of the administrated doses of L-759,633 reached their peak at the 60-min. In the tail flick test, the obtained \% MPE values by 3, 6 and $12 \mathrm{mg} / \mathrm{kg} \mathrm{L}$ 759,633 at the 60 -min were respectively 30.67 $\pm 5.46,62.83 \pm 4.26,74.30 \pm 9.746$ while in the hot plate test, the obtained values were respectively $18.62 \pm 2.48,34.81 \pm 5.31,52.93 \pm$ 6.79 . 

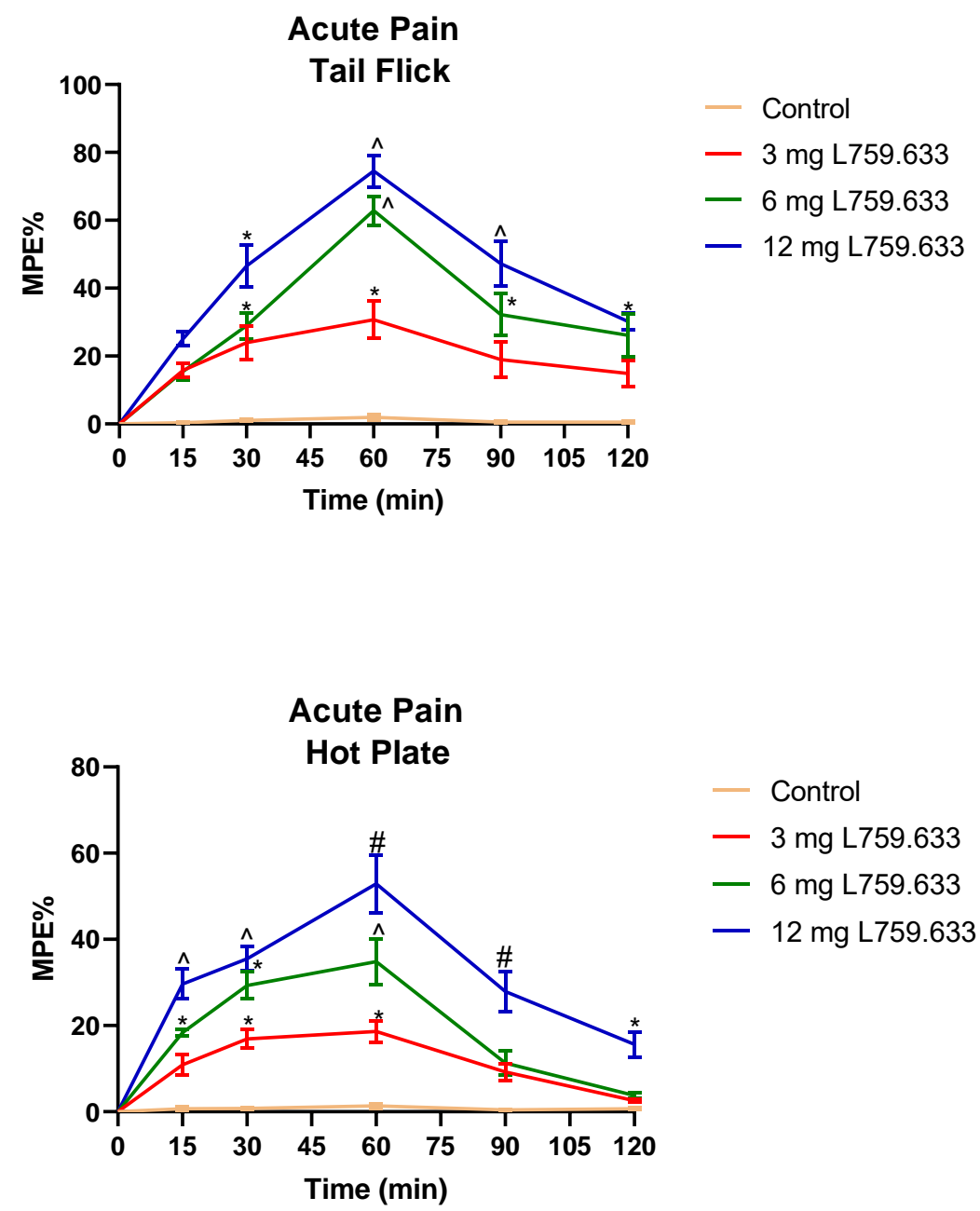

Fig. 2: The antinociceptive effects of different doses of L-759,633 in the acute pain model using tail flick test (A) and hot plate test (B).These effects were expressed as percent of maximal possible effect (MPE). L759,633 was applied intraperitoneally. Each point represents the mean \pm SEM of $\%$ MPE for 6 rats. $(*)$ There was a significant analgesic effect compared to the control group $(* p<0.05) .\left({ }^{\wedge}\right)$ There was a significant analgesic effect compared to the control group and this analgesic effect was significantly higher than that of $3 \mathrm{mg} / \mathrm{kg} \mathrm{L}-759,633$ group $(\wedge \mathrm{p}<0.05)$. (\#)There was a significant analgesic effect compared to the control group and this analgesic effect was significantly higher than that of 3 and $6 \mathrm{mg} / \mathrm{kg} \mathrm{L}-759,633$ groups (\#p $<0.05)$.

\section{Comparison between Antinociceptive Effects of L-759,633 and SER601 in the Acute Pain Model}

In the tail flick test, the antinociceptive effects of 3,6 and $12 \mathrm{mg} / \mathrm{kg}$ SER601 in the acute pain were more than the L-759,633 groups at the same doses. On the other hand, there was no statistically significant difference between the antinociceptive effect of $3 \mathrm{mg} / \mathrm{kg}$ SER601 and $6 \mathrm{mg} / \mathrm{kg} \mathrm{L}-$ 759,633 and between the antinociceptive effect of $6 \mathrm{mg} / \mathrm{kg}$ SER601 and $12 \mathrm{mg} / \mathrm{kg} \mathrm{L-759,633} \mathrm{(Fig.}$ $3 \mathrm{~A})$. In the hot plate test, the antinociceptive effects of 3,6,12 $\mathrm{mg} / \mathrm{kg}$ SER601 in the acute pain were not different from L-759,633 groups at the same doses (Fig. 3B). 

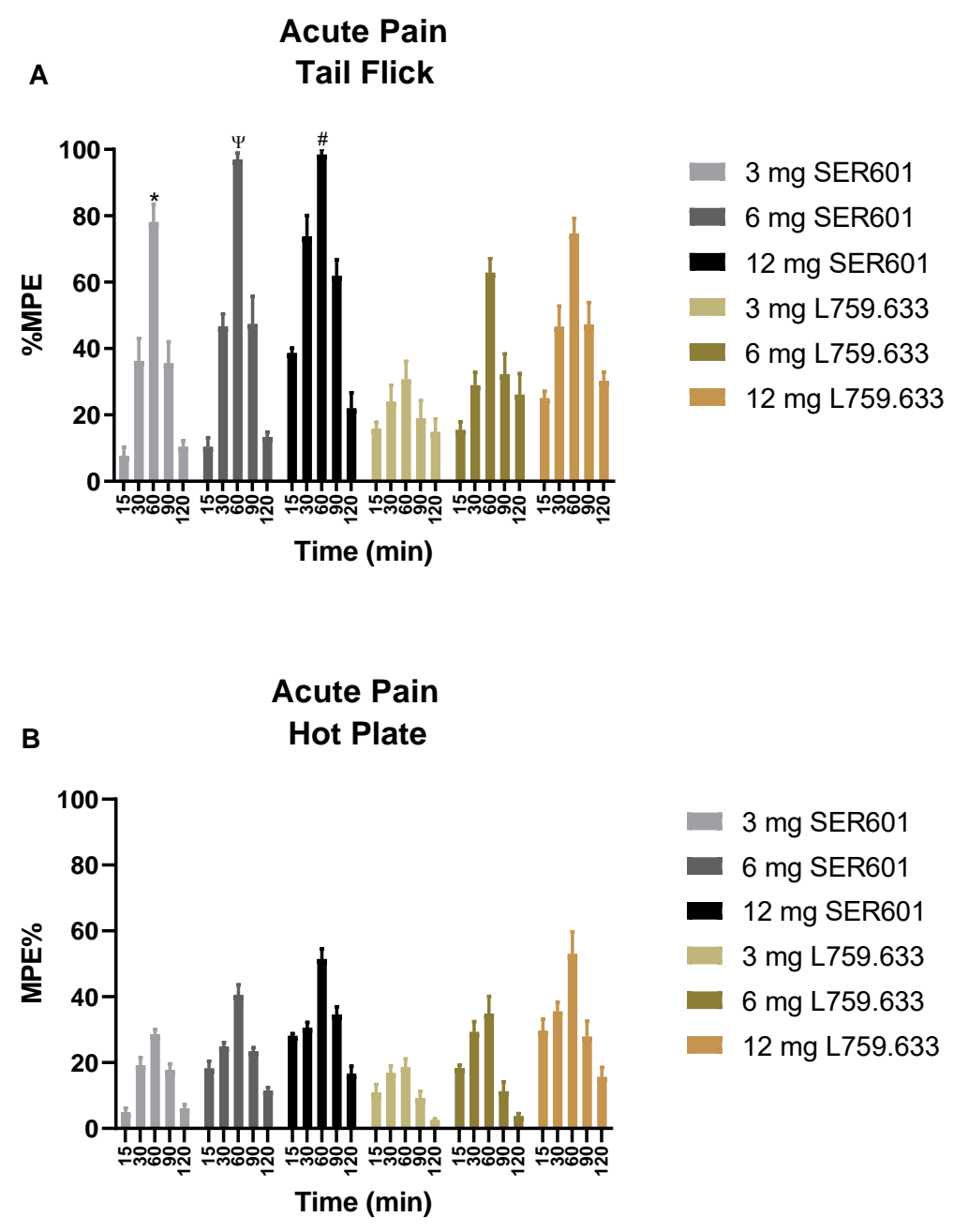

Fig. 3: The antinociceptive effects of L-759,633 and SER601 in the acute pain model using tail flick test (A) and hot plate test (B).These effects were expressed as percent of maximal possible effect (MPE). L-759,633 and SER601 were applied intraperitoneally. Each point represents the mean of \% MPE for 6 rats. In the tail flick test (A): The analgesic effect of $3 \mathrm{mg} / \mathrm{kg}$ SER601 group was significantly higher than that of $3 \mathrm{mg} / \mathrm{kg}$ L-759,633 group $(* \mathrm{p}<0.05)$. The analgesic effect of $6 \mathrm{mg} / \mathrm{kg}$ SER601 group was significantly higher than that of $6 \mathrm{mg} / \mathrm{kg} \mathrm{L}-759,633$ group $(\wedge \mathrm{p}<0.05)$. The analgesic effect of $12 \mathrm{mg} / \mathrm{kg}$ SER601 group was significantly higher than that of $12 \mathrm{mg} / \mathrm{kg} \mathrm{L}-759,633$ group (\#p <0.05). In the hot plate test (B): No statistically significant differences were found between the analgesic effects of 3,6 and, $12 \mathrm{mg} / \mathrm{kg} \mathrm{SER} 601$ and those of the same doses of L-759,633 ( $p>0.05$ ).

\section{DISCUSSION}

The acute pain medication stays an important clinical problem, partly because of the undesired neural side-effects that limit the clinical effectiveness of opioids which are used frequently for the medication of moderate-to-severe pain. Current preclinical evidences have demonstrated that $\mathrm{CB}_{2}$ cannabinoid receptor-selective agonists are promising for the acute pain treatment without causing CNS side effects ${ }^{18}$. The $\mathrm{CB}_{2}$ receptorselective agonist AM1241 inhibits acute nociception. Above all, AM1241 did not produce effects on the central nervous system, including those normally produced by $\mathrm{CB}_{1} \mathrm{R}$ agonists ${ }^{19}$. It was suggested that $\mathrm{CB}_{2} \mathrm{R}$ agonists HU-308 ${ }^{20}$ and GW405833 ${ }^{21}$ produced peripheral analgesic activity. In this study, the $\mathrm{CB}_{2} \mathrm{R}$ agonists SER601 and L-759,633 were applied in three different doses $(3,6$, and $12 \mathrm{mg} / \mathrm{kg})$. These two agents exhibited dose-dependent antinociceptive effect in acute pain model. Our finding is consistent with previous findings as $\mathrm{CB}_{2} \mathrm{R}$ agonists have analgesic effects in an acute pain model. The antinociceptive effects of these drugs reached their peak at 60 mins after injection and then began to decrease. In the tail flick assay the 
analgesic effects of these doses of SER601 in acute pain were more than those of the same doses of L-759,633. However in the hot plate assay there was no difference between the analgesic effects of these agents. While the nociceptive response in the hot plate method is caused by spinal and supraspinal mechanisms, the nociceptive response in the tail flick method is primarily related with spinal mechanisms ${ }^{22,}{ }^{23}$. While in the tail flick method the antinociceptive activity of the SER601 in the acute pain model was greater than that of the L-759,633, in the hot plate method no significant difference was shown. Based on this, the participation of spinal mechanisms in the antinociceptive activity of the SER601 in the acute pain model may be higher than that of L-759,633. Certainly, these results need to be proved by more preclinical and clinical studies. The study of antinociceptive effects of $\mathrm{CB}_{2}$ agonists deserves further attention, as these drugs do not produce central side effects and exhibit strong antinociceptive effects in many studies.

\section{CONCLUSION}

SER601 and L-759,633 exhibited dose-dependent antinociceptive effect in acute pain model. The analgesic effects of the administrated doses of L759,633 and SER 601 reached their peak at 60 min. While in the tail flick method the antinociceptive activity of the SER601 in the acute pain model was greater than that of the L759,633 , in the hot plate method no significant differences were shown.

Ethical approval: All procedures performed in studies involving animals were in accordance with the ethical standards of the institution or practice at which the studies were conducted. Animal experimental procedures were approved by the Animal Ethical Committee at Cumhuriyet University (Sivas, Turkey).

Authors Contributions: ZJ designed and conduct the study and wrote the manuscript. BS conducted and analyzed the experiments. ŞY supervised the study. All authors read and approved the manuscript. The authors declare that all data were generated in-house and that no paper mill was used.

Acknowledgments: This study was funded by Sivas Cumhuriyet University Scientific Research Project (T-848, Doctoral Thesis Project, CUBAP, Turkey).

Conflict of Interests: The authors declare that they have no conflict of interest.

\section{REFERENCES}

1. Steeds CE. The anatomy and physiology of pain. Surgery. 2009;27(12):507-511. doi:10.1016/j.mpsur.2009.10.013

2. Koneti KK, Jones M. Management of acute pain. Surg (United Kingdom). 2013;31(2):7783. doi:10.1016/j.mpsur.2012.12.004

3. Cohen SP, Mao J. Neuropathic pain: Mechanisms and their clinical implications. BMJ. 2014;348. doi:10.1136/bmj.f7656

4. Khan A, Khan S, Kim YS. Insight into Pain Modulation: Nociceptors Sensitization and Therapeutic Targets. Curr Drug Targets. 2019;20(7):775-788. doi:10.2174/1389450120666190131114244

5. Katz N. The impact of pain management on quality of life. In: Journal of Pain and Symptom Management. Vol 24. J Pain Symptom Manage; 2002. doi:10.1016/S08853924(02)00411-6

6. Starowicz K, Finn DP. Cannabinoids and Pain: Sites and Mechanisms of Action. In: Advances in Pharmacology. Vol 80. Academic Press Inc.; 2017:437-475. doi:10.1016/bs.apha.2017.05.003

7. Koob GF. The neurobiology of addiction: A neuroadaptational view relevant for diagnosis. Addiction. 2006;101(SUPPL. 1):23-30. doi:10.1111/j.1360-0443.2006.01586.x

8. Yuill MB, Hale DE, Guindon J, Morgan DJ. Anti-nociceptive interactions between opioids and a cannabinoid receptor 2 agonist in inflammatory pain. Mol Pain. 2017;13. doi:10.1177/1744806917728227

9. Pertwee RG. Pharmacology of cannabinoid CB1 and CB2 receptors. Pharmacol Ther. 1997;74(2):129-180. doi:10.1016/S01637258(97)82001-3

10.Pacher P, Kunos G. Modulating the endocannabinoid system in human health and disease - Successes and failures. FEBS $J$. 2013;280(9):1918-1943. doi:10.1111/febs. 12260

11. Tanda G, Goldberg SR. Cannabinoids: Reward, dependence, and underlying neurochemical mechanisms - A review of recent preclinical data. Psychopharmacology (Berl). 2003;169(2):115-134. doi:10.1007/s00213-003-1485-z

12. Deng L, Guindon J, Cornett BL, Makriyannis A, Mackie K, Hohmann AG. Chronic cannabinoid receptor 2 activation reverses 
paclitaxel neuropathy without tolerance or cannabinoid receptor 1-dependent withdrawal. Biol Psychiatry. 2015;77(5):475-487. doi:10.1016/j.biopsych.2014.04.009

13. Kinsey SG, Mahadevan A, Zhao B, et al. The CB2 cannabinoid receptor-selective agonist O3223 reduces pain and inflammation without apparent cannabinoid behavioral effects. Neuropharmacology. 2011;60(2-3):244-251. doi:10.1016/j.neuropharm.2010.09.004

14. Guindon J, Hohmann AG. Cannabinoid CB 2 receptors: A therapeutic target for the treatment of inflammatory and neuropathic pain. Br J Pharmacol. 2008;153(2):319-334. doi:10.1038/sj.bjp.0707531

15. Kanaan SA, Saadé NE, Haddad JJ, et al. Endotoxin-induced local inflammation and hyperalgesia in rats and mice: A new model for inflammatory pain. Pain. 1996;66(2-3):373379. doi:10.1016/0304-3959(96)03068-0

16. Ramabadran K, Bansinath $\mathrm{M}$, Turndorf $\mathrm{H}$, Puig MM. The hyperalgesic effect of naloxone is attenuated in streptozotocin-diabetic mice. Psychopharmacology (Berl). 1989;97(2):169174. doi:10.1007/BF00442244

17. Demirkazik A, Ozdemir E, Arslan G, Taskiran AS, Pelit A. The effects of extremely lowfrequency pulsed electromagnetic fields on analgesia in the nitric oxide pathway. Nitric Oxide - Biol Chem. 2019;92:49-54. doi:10.1016/j.niox.2019.08.003

18. Ibrahim MM, Rude ML, Stagg NJ, et al. CB2 cannabinoid receptor mediation of antinociception. Pain. 2006;122(1-2):36-42. doi:10.1016/j.pain.2005.12.018

19. Malan TP, Ibrahim MM, Deng H, et al. CB2 cannabinoid receptor-mediated peripheral antinociception. Pain. 2001;93(3):239-245. doi:10.1016/S0304-3959(01)00321-9

20. Hanuš L, Breuer A, Tchilibon S, et al. HU308: A specific agonist for CB2, a peripheral cannabinoid receptor. Proc Natl Acad Sci U S A. 1999;96(25):14228-14233. doi:10.1073/pnas.96.25.14228

21. Valenzano KJ, Tafesse L, Lee G, et al. Pharmacological and pharmacokinetic characterization of the cannabinoid receptor 2 agonist, GW405833, utilizing rodent models of acute and chronic pain, anxiety, ataxia and catalepsy. Neuropharmacology. 2005;48(5):658-672. doi:10.1016/j.neuropharm.2004.12.008

22. Rezaee-Asl M, Sabour M, Nikoui V, Ostadhadi S, Bakhtiarian A. The Study of Analgesic Effects of Leonurus cardiaca L. in Mice by Formalin, Tail Flick and Hot Plate Tests . Int Sch Res Not. 2014;2014:1-5. doi:10.1155/2014/687697

23. Fan SH, Ali NA, Basri DF. Evaluation of analgesic activity of the methanol extract from the galls of quercus infectoria (Olivier) in Rats. Evidence-based Complement Altern Med. 2014;2014. doi:10.1155/2014/976764 